\title{
Kelekatan Guru dan Motivasi Membaca
}

\author{
Gian Fitria Anggraini ${ }^{1}$ \\ ${ }^{1}$ PG PAUD FKIP Universitas Lampung, Jl. Prof. Dr. Soemantri Brojonegoro No. 1 \\ *email: gian.fitria21@ gmail.com
}

\begin{abstract}
Teacher Attachment and Reading Motivation. The research background is the lack of teacher attachment in developing children reading interest. Through a survey approach, this study aimed to describe the conditions of attachment between teacher and child toward children motivation to read. The sample was taken randomly, which consisted of 57 students in grade 3 of elementary school and two teachers. The data was collected by questionnaire and analyzed by using descriptive statistics. The results showed that students' reading motivation based on students' perceptions was in the medium category (40\%), while based on teachers' perceptions it was in the low category $(82.45 \%)$. The positive attachment that occurred was in the low category (63.15\%), while the negative attachment was in the low category (78.9\%). Teachers need to build positive attachment, especially in increasing students' motivation to read.
\end{abstract}

Keywords: attachment, teacher, reading motivation

Abstrak. Kelekatan Guru dan Motivasi Membaca. Penelitian ini dilatarbelakangi dengan minimnya kelekatan guru yang terbentuk terutama dalam mengembangkan minat baca. Melalui pendekatan survey, penelitian ini bertujuan untuk menggambarkan kondisi kelekatan atau attachment antara guru dan anak serta motivasi membaca. Sampel diambil secara acak, yang terdiri dari 57 siswa kelas 3 Sekolah Dasar dan dua orang guru.Teknik pengumpulan data yang akan digunakan berupa angket. Adapun data dianalis melalui statistic deskriptif. Hasil penelitian menunjukkan bahwa motivasi membaca siswa berdasarkan persepsi siswa termasuk kategori sedang (40\%), sedangkan berdasarkan persepsi guru termasuk kategori rendah $(82.45 \%)$. Kelekatan positif yang terjadi termasuk pada kategori rendah $(63.15 \%)$, sednagkan untuk kelekatan negatif termasuk kategori rendah (78.9\%). Guru perlu membangun kelekatan yang positif terutama dalam meningkatkan motivasi membaca siswa.

Kata Kunci: kelekatan, guru, motivasi membaca 


\section{PENDAHULUAN}

Pembelajaran literasi diperkenalkan sejak dini melalui berbagai aktivitas. Aktivitas literasi tidak hanya terkait pada membaca tapi juga menulis yang tujuannya adalah untuk meningkatkan keterampilan dalam mengubah, meringkas, memodifikasi, serta menceritakan kembali suatu kisah dari sebuah buku (Litbang, 2011). Guru salah satunya menjadi kunci pada pengenalan literasi dini.

Beberapa penelitian menunjukkan bahwa salah satu komponen yang dapat meningkatkan kemampuan anak dalam literasi adalah adanya faktor kelekatan atau kedekatan yang intens dan cukup mendalam antara anak dengan guru (Rudasill, 2011; Verschueren \& Koomen, 2012). Kelekatan (attachment) sering kali menjadi suatu hal yang terlupakan dalam proses pembelajaran. Padahal kelekatan ini adalah bagian dari interaksi atau komunikasi antara guru dan anak. Salah satu kompetensi yang harus dimiliki oleh guru adalah kompetensi sosial, yang di dalamnya mengandung kemampuan guru dalam melakukan interaksi, kerjasama serta menjaga relasi baik itu dengan siswa, rekan kerja maupun orang tua. Kemampuan dalam menjaga hubungan atau kelekatan yang baik dengan anak menjadi salah satu keharusan bagi guru terutama dalam memenuhi kompetensi sosial maupun kompetensi lainnya.

Tidak hanya faktor kelekatan yang dapat menunjang dalam pembelajaran literasi, namun ketersediaan lingkungan, baik itu sarana maupun prasarana, menjadi salah satu pendukung yang tidak dapat dilupakan begitu saja. Beberapa penelitian menunjukkan bahwa penyediaan lingkungan yang literat, baik itu di rumah maupun di sekolah dapat membantu anak dalam meningkatkan kegiatan literasinya (Niklas \& Schneider, 2013; Pinto, Pessanha, \&
Aguiar, 2013). Hal ini menunjukkan bahwa penyediaan lingkungan yang literat, menjadi satu paradigma yang perlu diperhatikan terutama untuk mendukung anak memiliki rasa ingin tahu untuk mengeksplorasi lingkungannya melalui bahan bacaan, serta memberikan kesempatan pada anak untuk terbiasa berada pada lingkungan yang literat, sebelum pada akhirnya mereka menyukai membaca.

Kemampuan literasi, terutama dalam minat membaca, tentunya membutuhkan suatu usaha serius yang perlu didukung melalui penelitian. Sementara itu, beberapa hasil penelitian membuktikan bahwa kegiatan literasi, baik itu membaca maupun menulis dapat ditingkatkan melalui lingkungan yang literat serta interaksi yang baik antara guru dan anak. Berdasarkan permasalahan yang masih ditemukan, penelitian ini bermaksud untuk mengkaji kelekatan antara guru dan anak dalam pembelajaran literasi, terutama minat membaca.

\section{METODE}

Penelitian ini menggunakan metode survey. Lokasi pengambilan data di Bandar Lampung. Jumlah sampel adalah 106 siswa dan 2 orang guru SD kelas 3. Sampel diambil dengan menggunakan teknik random sampling.

Proses pengumpulan data dilakukan melalui instrumen berupa angket yang digunakan untuk menggambarkan motivasi membaca siswa dari perspektif siswa maupun guru, serta untuk menggambarkan pola interaksi (attachment) antara guru dan anak. Angket motivasi membaca siswa menggunakan motivations for reading questionnaire (MRQ) yang terdiri dari 53 item (Wigfield \& Guthrie, 1997). Skala penilaian menggunakan skala likert, dengan skor 1 sampai 4 (1 tidak suka, 2 kurang suka, 3 cukup suka, 4 sangat 
suka). Adapun reliabilias instrumen adalah sebesar 0.80 .

Angket motivasi membaca siswa berdasarkan persepsi guru menggunakan teacher questionnare on student motivation to read (Sweet \& Guthrie, 1996). Angket terdiri dari 31 item dengan 4 skala penilaian. 1 tidak pernah, 2 jarag, 3 kadang-kadang, 4 sering.

Angket interaksi (attachment) guruanak menggunakan student-teacher relationship scale (STRS) (Pianta 1995). Angket terdiri dari 28 item, dengan 5 skala penilaian (1 sama sekali tidak pernah melakukan, 2 tidak terlalu melakukan, 3 netral, tidak yakin, 4 kadang melakukan, 5 sering melakukan).

Data dianalisis melalui statistik deskriptif untuk mencari persentase, kategori, mean, standar deviasi, serta nilai minimal dan maksimal.

\section{HASIL DAN PEMBAHASAN HASIL}

\section{Motivasi Membaca berdasarkan Perspesi Siswa}

Dari hasil olah data maka diperoleh kondisi sebagai berikut:

Tabel 1. Sebaran persepsi siswa berdasarkan motivasi membaca siswa

\begin{tabular}{cccc}
\hline No & Kategori & n & \% \\
\hline 1 & Rendah & 14 & 25.00 \\
2 & Sedang & 23 & 40.00 \\
3 & Tinggi & 20 & 35.00 \\
\hline Jumlah & 57 & 100.00 \\
Min-Max & $157-212$ \\
Rata-rata \pm Std & $189.70 \pm 13.475$ \\
\hline
\end{tabular}

Dari tabel (1) dapat kita simpulkan bahwa motivasi membaca siswa untuk kategori rendah 25\%, sedangkan kategori sedang 40\%, dan kategori tinggi $35 \%$. Artinya bahwa berdasarkan persepsi siswa, motivasi membaca mereka masih belum optimal, masih ada dalam batas sedang.

\section{Motivasi Membaca Siswa Berdasarkan Persepsi Guru}

Hasil olah data dapat dilihat pada tabel (2) berikut:

Tabel 2. Sebaran persepsi guru berdasarkan kategori motivasi membaca

\begin{tabular}{clcc}
\hline No & Kategori & n & \% \\
\hline 1 & Rendah & 47 & 82.45 \\
2 & Sedang & 6 & 10.52 \\
3 & Tinggi & 4 & 7.01 \\
\hline Jumlah & 57 & 100 \\
Min-Max & \multicolumn{2}{c}{$96-114$} \\
Rata-rata \pm Std & $102.73 \pm 3.258$ \\
\hline
\end{tabular}

Dari hasil penelitian dapat diketahui bahwa berdasarkan persepsi guru, motivasi membaca siswa masih dalam kategori rendah, yaitu sebesar $82.45 \%$. Sedangkan untuk kategori tinggi masih sebesar $7.01 \%$. Hal ini menunjukkan bahwa antara persepsi guru dan siswa ada sedikit perbedaan, dimana siswa merasa bahwa motivasi mereka sudah cukup baik dalam membaca, namun guru menilai bahwa siswa tersebut belum memiliki motivasi yang maksimal.

\section{Kelekatan Guru dan Siswa}

Dari hasil olah data juga diketahui kondisi kelekatan positif antara guru dan siswa yang masuk pada kategori rendah sebanyak $63.15 \%$, kategori sedang $7.01 \%$, dan kategori tinggi $29.82 \%$. Hal ini menunjukkan bahwa kelekatan positif antara guru dan siswa masih tergolong rendah.

Tabel 3. Sebaran kategori Kelekatan Positif Guru-Anak

\begin{tabular}{clcc}
\hline No & Kategori & n & \% \\
\hline 1 & Rendah & 36 & 63.15 \\
2 & Sedang & 4 & 7.01 \\
\hline
\end{tabular}




\begin{tabular}{lcc}
\hline \multicolumn{1}{c}{ Tinggi } & 17 & 29.82 \\
\hline Jumlah & 57 & 100 \\
Min-Max & $40-59$ \\
Rata-rata \pm Std & $47.41 \pm 8.118$ \\
\hline
\end{tabular}

Dari hasil olah data juga diketahui kondisi kelekatan positif antara guru dan siswa yang masuk pada kategori rendah sebanyak $63.15 \%$, kategori sedang $7.01 \%$, dan kategori tinggi $29.82 \%$. Hal ini menunjukkan bahwa kelekatan positif antara guru dan siswa masih tergolong rendah

Tabel 4. Sebaran kategori Kelekatan Negatif Guru-Anak

\begin{tabular}{clcc}
\hline No & Kategori & n & \% \\
\hline 1 & Rendah & 45 & 78.9 \\
2 & Sedang & 6 & 10.52 \\
3 & Tinggi & 6 & 10.52 \\
\hline Jumlah & 57 & 100 \\
Min-Max & \multicolumn{2}{c}{$43-77$} \\
Rata-rata \pm Std & $48.55 \pm 9.046$ \\
\hline
\end{tabular}

Hasil olah data juga menggambarkan bagaimana kondisi kelekatan negatif antara guru dan siswa. Diketahui bahwa untuk kategori rendah sebanyak 78.9\%, kategori sedang dan tinggi, masingmasing di bawah 15\%. Hal ini menunjukkan bahwa kelekatan negatif antara guru dan siswa juga termasuk pada kategori rendah. Dari dua data di atas menggambarkan bahwa relasi kelekatan antara guru dan anak masih memiliki kelekatan yang rendah, baik itu dari sisi positif maupun negatif.

\section{PEMBAHASAN}

Dari hasil penelitian ditemukan bahwa pendekatan yang dilakukan oleh guru dalam memahami karakteristik siswa, secara tidak langsung dapat mempengaruhi bagaimana guru mempersepsikan kemampuan maupun kapasitas siswa dalam belajar maupun beraktifitas. Proses kelekatan yang masih belum terbentuk dari dalam guru kepada siswa, dapat membuat penilaian yang kurang tepat terhadap kemampuan anak. Hal ini dapat dilihat dari hasil penelitian bahwa meskipun siswa mempersepsikan dirinya memiliki kapasitas yang cukup untuk membaca, namun ada suatu potensi yang belum terbaca oleh guru, yang diakibatkan oleh proses kelekatan atau hubungan anatara guru dan anak yang belum terbentuk secara optimal.

Meskipun guru mempersepsikan motivasi membaca siswa masih dalam kategori rendah, namun dari sisi siswa, mereka mempersepsikan dirinya sudah memiliki motivasi yang cukup memadai. Adapun ketidakselarasan persepsi ini, salah satunya dapat dipengaruhi oleh kurangnya hubungan atau interaksi serta kelekatan diantara guru dan siswa, sehingga guru belum dapat memenuhi seluruh kebutuhan serta kompetensi siswa yang sesungguhnya, terutama dalam hal membaca. Beberapa teori yang berkaitan dengan attachment menyebutkan bahwa perkembangan rasa aman pada hubungan antara anak dan orang dewasa berkaitan dengan sensitifitas orang dewasa. Hal ini menunjukkan bahwa kualitas hubungan antara anak dan guru tidak hanya ditentukan oleh sejarah kelekatan yang dimiliki anak, namun juga kondisi perilaku serta sensitivitas guru secara umum (Kobak 1999).

Menjaga kelekatan (attachment) dengan anak menjadi salah satu indikator dalam keterpenuhan pencapaian pembelajaran. Kelekatan ini secara tidak langsung akan mendorong anak untuk meningkatkan kemampuan literasinya, melalui dukungan yang didapatkan dari guru maupun orang dewasa. Dukungan yang penuh ini tidak akan terbentuk dengan baik, jika tidak terbangun kelekatannya. Hal inilah yang menjadi poin penting bahwa pola kelekatan antara guru dan anak perlu 
dikembangkan dan dikaji terus-menerus (Mitchell-Copeland, Denham, \& DeMulder, 1997; Rudasill \& RimmKaufman, 2009; Verschueren \& Koomen, 2012).

Pada kasus interaksi antara anak dan guru, kedekatan ini berkorelasi dengan rasa nyaman, perasaan serta pengalaman, dimana anak menjadikan guru sebagai sumber support (pendukung) dan yang menenangkan saat merasa kecewa (Pianta, Steinberg \& Rollins 1995). Hal ini menunjukkan bahwa rasa nyaman siswa terhadap situasi atau iklim belajar di kelas setidaknya dapat mempengaruhi mood atau antusiasme dalam melakukan aktifitas belajar, salah satunya adalah membaca.

\section{SIMPULAN DAN SARAN}

Berdasarkan hasil penelitian ditemukan bahwa ada ketidakselarasan anatara persepsi siswa dan guru terhadap motivasi membaca. Guru mempersepsikan motivasi siswa masih dalam kategori rendah, sedangkan siswa mempersepsikan dirinya sudah memiliki motivasi yang cukup baik dalam membaca. Penggambaran kondisi kelekatan juga menunjukkan bahwa kondisi kelekatan positif maupun negatif antara guru dan siswa masih tergolong rendah.

Penelitian dapat dilanjutkan atau diperdalam dengan menggali lagi hambatan atau tantangan yang dihadapi oleh guru berkaitan dengan upaya meningkatkan kelekatan serta motivasi dalam membaca. Penelitian dengan metode kualitatif dapat menjadi pilihan untuk menggali lebih dalam lagi tentang pola kelekatan serta lingkungan yang literat pada anak usia dini

\section{REFERENSI}

Kobak, R. (1999). The emotional dynamics of disruptions in attachment relationships: Implications for theory, research, and clinical intervention. In J. Cassidy \& P. R. Shaver (Eds.), Handbook of attachment: Theory, research, and clinical applications (pp. $21-43$ ). New York: Guilford.

Litbang. (2011). Laporan Kemampuan Membaca Anak Indonesia Dunia. Jakarta: Data Puspendik.

Mitchell-Copeland, J., Denham, S. A., \& DeMulder, E. K. (1997). Q-Sort Assessment of Child-Teacher Attachment Relationships and Social Competence in the Preschool. Early Education \& Development, 8(1), 27-39. https://doi.org/10.1207/s155669 35eed0801_3

Niklas, F., \& Schneider, W. (2013). Home Literacy Environment and the beginning of reading and spelling. Contemporary Educational Psychology, 38(1), 40-50.

https://doi.org/10.1016/j.cedpsyc h.2012.10.001

Pianta, R. C., Steinberg, M. S., \& Rollins, K. B. (1995). The first two years of school: Teacherchild relationships and deflections in children's classroom adjustment. Development and Psychopathology, 7, 295-312.

Pinto, A. I., Pessanha, M., \& Aguiar, C. (2013). Effects of home environment and center-based child care quality on children's language, communication, and literacy outcomes. Early Childhood Research Quarterly, 28(1), 94-101. 
https://doi.org/10.1016/j.ecresq. 2012.07.001

Rudasill, K. M. (2011). Child temperament, teacher-child interactions, and teacher-child relationships: A longitudinal investigation from first to third grade. Early Childhood Research Quarterly, 26(2), 147-156. https://doi.org/10.1016/j.ecresq. 2010.07.002

Rudasill, K. M., \& Rimm-Kaufman, S. E. (2009). Teacher-child relationship quality: The roles of child temperament and teacherchild interactions. Early Childhood Research Quarterly, 24(2), 107-120. https://doi.org/10.1016/j.ecresq. 2008.12.003

Sweet, A.P \& Guthrie, J.T. (1996). Teachers' Perceptions and Students' Literacy Motivations. Reading Research Report Number 69. Universities Georgia and Maryland: National Reading Research Center.

Wigfield, A. \& Guthrie, J.T. (1997). Relations of children's motivation for reading to the amount and breadth of their reading. Journal of Educational Psychology, 89, 420-432

Verschueren, K., \& Koomen, H. M. Y. (2012).

Teacher-child relationships from an attachment perspective. Attachment \& Human Development, 14(3), 205-211. https://doi.org/10.1080/1461673 4.2012.672260 